Figura 6. Ejemplo de la figura de evolución poblacional de acuáticas invernantes, para el silbón común

\title{
Silbón común
}

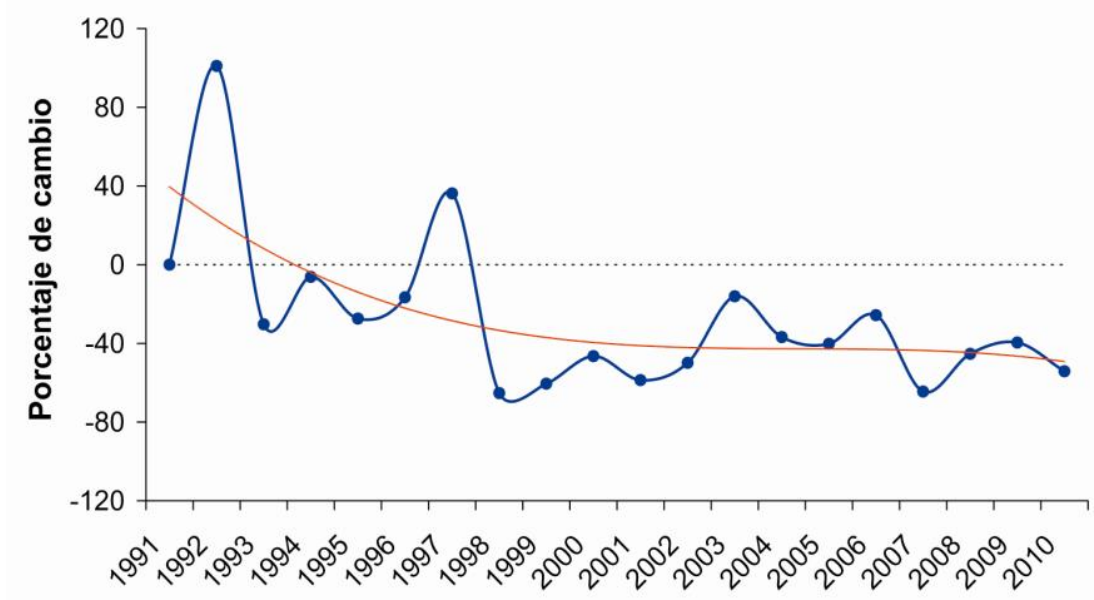

Ana Bermejo, David Palomino, Blas Molina y Juan Carlos del Moral Área de Estudio y Seguimiento de Avifauna. SEO/BirdLife

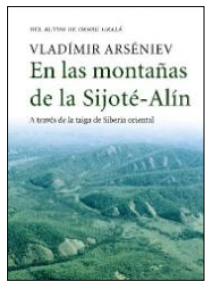

Vladímir ARSÉNIEV: En las montañas de la SijotéAlín. Ediciones Península, Barcelona, 2007. 318 pp. Traducción de Miquel Cabal Guarro [ISBN: 978-848307-790-0]

Es una buena noticia la publicación en castellano por primera vez, si no me fallan mis indagaciones, de esta obra de Vladímir Arséniev, que viene a ser como "la hermana menor" de su narración más conocida titulada "Dersú Uzalá"; relato que con el subtítulo de "El Cazador" fue llevado al cine exitosamente por el director japonés Akira Kurosawa. Esta película nos marcó a muchas personas (geógrafos incluidos) en la forja de una relación mixta de respeto y curiosidad con respecto a la naturaleza. Con bastante retraso ha llegado la traducción impresa de esta obra del capitán ruso de los ejércitos 
zarista y soviético, que realizó y narró doce expediciones por Siberia Oriental entre los años 1902 y 1930. Ha llegado el libro bien avanzada la primera década del siglo XXI; y con eco amplio gracias al suplemento bibliográfico del periódico diario con más lectores según la Encuesta General de Medios de Difusión de España (EGME). Ha pasado, pues, casi un siglo desde que V. Arséniev escribiera esta obra estructurada en catorce capítulos de muy irregular extensión, pues oscilan entre cuatro y sesenta páginas, aunque lo más común es la amplitud capitular de la veintena. Esta diversidad desequilibradora parece un descuido para una obra de narrativa fluida; pero no es esto lo que sucede, ya que el autor lo que pretende es sumar relatos para recordar y aprender de sus jornadas viajeras; es decir, no parecen narraciones dedicadas a la difusión abierta al gran público. Se trata de recuerdos, anécdotas, incidentes, peligros y curiosidades sobre la naturaleza y los grupos étnicos que encontró en la región al Norte del bajo río Amur hasta el océano Pacífico, que se conoce como "La Sijoté-Alín". Se trata de una cadena montañosa, alargada en sentido meridiano y paralela a la costa oceánica, que con frecuencia alcanza altitudes entre 1.000 y 2.700 metros en latitudes relativamente bajas de $43^{\circ}$ a $49^{\circ}$ Norte entre las ciudades litorales de Vladivostok por el Sur y Sovieskaya Gavan por el Norte, que es donde termina la narración.

El contenido de los relatos (organizados en jornadas) es muy variado, entretenido, sugerente e ilustrativo para las personas amantes de la naturaleza y para el bagaje científico y cultural de cualquier geógrafo tanto especialista en el medio físico como en la actividad humana. Hay mucha y variada información en estos relatos viajeros, que estimo constituyen un jalón importante en el desarrollo del nudo cimentador de la Geografía como ciencia y saber, que es "el Hombre sobre la Tierra" en palabras lúcidas del gran geógrafo Max Sorre. Bien es verdad que V. Arséniev no es geógrafo, si bien con sus doctos y sensibles relatos hace el oficio de un buen geógrafo. Queda claro que el autor es un topógrafo que establece cotas y realiza mediciones técnicas de altitudes y distancias; pero también menudean las observaciones sobre el roquedo, las formas del relieve, la vegetación, la fauna y los humedales como aspectos del medio físico, entre los que destacan el hecho poco conocido de la presencia de renos en tan bajas latitudes, la sorprendente alusión a "los alcornoques" del Amur o la explicación detallada del raro fenómeno meteorológico de los "rayos esféricos" (páginas 109-111). Entre los aspectos de la presencia humana en el territorio sobresalen las costumbre de varias grupos étnicos, dos descripciones de curas por chamanes (palabra de origen siberiano que significa "el que sabe") y el respeto siempre a las poblaciones indígenas y a sus muy diversas tradiciones. Hay amor a la naturaleza en la narrativa de V. Arséniev, al modo de hoy en organizaciones como el World 
Wildelife Found, y sincero respeto a las personas y tradiciones de las poblaciones indígenas al modo de organizaciones actuales como Survival, lo que nada tiene que ver con mentalidades colonialistas explotadoras ni con algunas prácticas misioneras de instituciones religiosas. Peca el autor de reiteración en descripciones de los cursos fluviales y deja un tanto insatisfecha la curiosidad de explicaciones científicas detalladas. Esto podría haberse solucionado en gran parte, si el traductor hubiera aportado algo más que dieciséis breves notas a pie de página a lo largo de toda la obra. En suma, se echa mucho en falta las aclaraciones de algún asesor científico con formación de naturalista; es decir, las aportaciones de algún buen profesional de la Geografía o de las Ciencias de la Naturaleza y la Antropología, que habrían podido completar y argumentar mejor bastantes de las experiencias viajeras del autor. No se ha sacado ni mucho menos todo el partido científico a la obra de V. Arséniev en esta publicación. La editorial ha planteado esta edición para un público muy amplio que no vaya más allá de la epidermis de una rápida ruta viajera convencional. Falta una biografía sobre el autor, una introducción sobre el contexto histórico-social en que se desarrolla esta obra y muchas y más ilustrativas notas a pie de página del traductor y de los asesores científicos (en esta edición no existen). No obstante, bienvenida sea esta publicación, pero sería muy interesante una nueva edición con buenos traductores y asesores científicos tanto de esta obra como de otras de V. Arséniev.

Guillermo Calonge Cano 